\title{
Reason for the Family Doing Confinement on People with Mental Disorders
}

\author{
Nining Wuri Lestari ${ }^{1}$, Setyawati Soeharto ${ }^{2}$, Heni Dwi Windarwati ${ }^{3}$ \\ ${ }^{1}$ Master Program of Nursing, Faculty of Medicine, Brawijaya University, Malang, Indonesia \\ ${ }^{2,3}$ Faculty of Medicine, Brawijaya University, Malang, Indonesia \\ E-mail: niningwlestari@gmail.com
}

\begin{abstract}
The number of retention is still high in Indonesia to find out the reasons for the family doing confinement on people with mental disorders in Trenggalek Regency. This research is a qualitative with an interpretative phenomenological approach. Data were obtained through indepth interviews with twelve families who treated people with post-pasung mental disorders in Trenggalek Regency. Data analysis using IPA (Interpretative Phenomenological Analysis), obtained four themes namely feeling frustrated with the patient's condition, feeling annoyed because of the patient's disobedience, the helplessness of the family doing something, bored because there is no meaningful development in the patient the family put up on people with mental disorders because they feel frustrated and helpless to face the patient's condition.
\end{abstract}

Keywords: Reason, Family, Confinement, People with Mental Disorders.

\section{A. INTRODUCTION}

Confinement is all forms of restriction of motion which results in loss of freedom of movement and health services (Stuart, 2016; Daulima \& Wardani, 2018). Inclusion in ODGJ is any form of limitation of movement in people who experience impaired thoughts, behaviors and feelings that result in loss of freedom of movement and the right to health services.

Forms of retention on most continents of North America and Europe use ropes, magnets or bonds placed in animal cages. On the African and Asian continents many chains are used to mount ODGJ(Molodynski, Brien \& Burns, 2017). Indonesia is a part of countries in Asia having a form of retention in the form of confinement in remote places, tied his feet with an iron chain, feet are burdened from wood or turn(Minas \& Diatri, 2008). ODGJ containment occurs in almost all continents and has a similarity with confinement and binding.

\section{B. METHOD}

This research is a qualitative research using interpretative phenomenology approach. Participants in this study were obtained by purposive sampling technique. The inclusion criteria of these participants were families who cared for post-pasung 
ODGJ, lived at home with post-pasung ODGJ, were willing to be interviewed and recorded by signing informed consent. Data were saturated in the twelfth participant. The study was carried out in February 2020 by exploring the reasons families are saving people with mental disorders in Trenggalek Regency by conducting in-depth interviews, using a semi-structured interview guide. Data analysis uses the principle of data analysis IPA (Interpretative Phenomenological Analysis) which consists of six steps, namely: reading and re-reading.

\section{DISCUSSION}

This study found four themes and the researcher will describe the overall theme formed from the results of the analysis based on participant expressions. The theme feels frustrated with the patient's condition participants revealed that they were "disappointed, angry and ashamed". This can be interpreted as participants feeling frustrated because there is an unpleasant feeling of having a child with a mental disorder, shame and expressions of anger. Frustration according to KBBI means a sense of disappointment due to failure in doing something. The expressions of participants' feelings are illustrated in the sub themes as follows:

\section{Sub theme: feeling disappointed}

Disappointed according to KBBI has the meaning of being discouraged, unsatisfied (because no wishes and wishes were fulfilled). The context of disappointment in this case is that participants feel disappointed because they have children who have mental disorders, the following quote:

"I was left by my husband when the children were still small, caring for 2 children is a lot of trouble, mom" (P1).

"... this plan used to be for the kitchen and then his house in front of it, because children are sick like this so finally they cannot make a house" (P7).

\section{Sub theme: angry}

Participants expressed anger because his wealth was used up to find his child's medicine but his child did not recover. In terms of the meaning of the word "angry" according to the KBBI is very not happy; angry by issuing words that indicate anger, the following statement with a rather high intonation, face tense when talking:

"Having only a little land is used up to treat B, around 24 days were treated there. Nothing has happened yet, JPS as of now there is no one still paying how much for one day, for buying one-time medicine to buy Rp. 300,000, - go home, yes, there are changes in the body feels good ". (P1). 
"... I tried myself how to run out all ma'am. This is pertasi (frustrated), my frustration is because I was so confused that I finally got nervous (brackets) "(P5).

\section{Sub theme: shame}

Participants expressed shame to their neighbors because of their family's mental illness and the act of confining patients. Embarrassed according to the KBBI is feeling very uncomfortable, the following statement:

"... the ones who asked to be released were neighbors. They chained their legs because they often took their neighbors' clothes and then their families felt ashamed"(P3).

"... going everywhere, sometimes we don't wear our clothes, shame, ma'am ... the neighbors and the RT head report to the Lurah then the Lurah reports to the Puskesmas" (P4).

\section{The theme is annoyed because of patient non-compliance}

Participants expressed annoyance with the patient's behavior, patients who did not follow the advice of parents who caused the pain worse. The annoyance according to KBBI is arouse resentment about something, the following statement:

"... I wanted to take a shower too but I was alone how come I don't want to. If the body feels good, it can't be told". (P1).

"... If you don't bathe it, you don't want to take a bath yourself, just stay in the room" (P2).

Participants felt annoyed because patients could not be independent and do as they wish, if advised not to heed, the following statement:

"... the bike has often been damaged, otherwise the wheels will come off. If it is damaged, I don't want to bring it to the garage, so I take it to the garage until it consumes a lot of money. Sometimes I even sell goats to buy him a bicycle. (P7). "... Never take a bath, ma'am, if you come here you will take a bath and shave your hair, but you don't want to". (P9)

".. after I got treated, I have prepared a room behind me, I gave a good bed linen, why on the wrecked, the clothes were moved to be carried everywhere, finally I just let it go how good it is". (P10).

"... at home when asked to remain silent later if forced to suddenly hit. Ladies and gentlemen have often been hit, once invited to the rice fields suddenly the paklik was thrown with stones until his head was sewn ". (P11)

Participants were annoyed with patients because it was difficult to take medicine and had to be seduced by giving cigarettes or money, the following statement: 
"... it is difficult, ma'am, if you give medicine, you will be enticed by cigarettes or money so that the medicine will be taken. If told to take medicine it is very difficult to be seduced first so that I want to ". (P3).

"... sometimes it can't be directed, if angry or annoyed with her husband he does not want to take medication ". (P4).

"... only that mas was feared, she used to give medicine, then she pretended to vomit. If it's the same, I just shake it ... if in the past I wanted to hit ". (P12)

\section{Theme feels helpless to do something}

Participants revealed that the family was helpless to do something because of the patient's behavior, the meaning of the theme was built up because they felt helpless, confused about facing the patient and traumatized by past events.

\section{Sub Theme: Powerless}

Powerless according to KBBI is feeling bad because of doing something and the inability to do something. Participants did not dare to force patients because they were afraid, could not fulfill the wishes of patients because there were grandchildren who had to be treated. The following participant quote:

"..I also don't dare to force you to be afraid. I told you that if you don't take a shower, it's not a shame if the neighbors come here, it doesn't smell good, the clothes change, but it's very difficult. (P1)

Participants cannot continue to treat patients because they already have own family, the following statement:

"... we cannot continue to care because we have to bother with family. Yes, I really don't have the heart, but what else can we do with siblings who already have their own families ". (P4)

"...sorry really ma'am but how else do I have nothing $m y$ child is still young, forced to ma'am. (P5)

Participants felt that there was no choice but to end the patient even though forced, the following statement:

"..from my trouble I also still take care of small children. ... if I stay later who is caring for, distant brothers ". (P6)

"... actually sorry for mom, Only the hands on the rope are still like that. Actually sorry for being upheld, can't bear it but how rather than damaging mom ". (P7)

"... my customer is lost because of fear. It often happens, many people who back off do not ask for my help. Finally I made a room behind it ". (P11). 


\section{Sub Theme: Confused}

Confused according to the KBBI is not knowing what to do. Participants felt confused if they wanted to leave because no one was delivering. The following participant expressions:

"... actually I have a problem, nobody will deliver if you want to go anywhere. Actually I am confused if I want to go, nobody will deliver. (P1)

Participants felt confused something happened to the patient and did not know what to do, the following statement:

"... go to the shaman ma'am because the family is confused not knowing if there is a cure" (P3).

"... actually the family is also confused when it's time to give birth." (P4)

Participants were confused about patients who often relapsed and were afraid of endangering others, following his statement:

"... I am very confused at this time how come why do I often relapse ... I am confused by the state of my mas because of frequent relapse". (P5)

"... happy because it's not raging anymore but if you know dipasung like that ya have a sense of pity mom". (P6)

"..confused. Yes, I'm confused, I'm a stupid person, I want to be invited to, just obey, because that invites the village chief and the crowd ". (P7)

"..I was confused even though I didn't know the cause .... I am confused how come this child continues to run amok. (P11)

\section{Sub Theme: Trauma}

Trauma according to KBBI is a mental state or abnormal behavior as a result of mental stress or physical injury. Participants felt traumatized by the events that had happened to them due to aggressive patient behavior. The following participant expressions:

"... I have been traumatized for a long time, ma'am, if someone suddenly comes without speaking, I am shocked to really be reminded of the trauma". (P1)

"...I was dragged there (the kitchen) after that one chicken coop was burned with him". (P12)

\section{Theme bored because there are no significant developments in patients,}

Participants expressed their feelings "bored because they have been treating patients for too long and the patient has not recovered," the phrase was obtained from the bored sub-theme. Bored according to KBBI is that I don't like it anymore because it's 
too often / too much; bored. Participants felt tired of finding a patient's medicine until the possessions were gone, the following participants said:

"If I don't give medicine, I will give it because I'm already bored, Mom, everything is gone ". (P1)

"... (Hoalah) have gone everywhere ma until all my possessions are gone... taken for treatment to smart people asked for expensive payment ". (P7)

"Yes, I have been to RSJ everywhere, never to smart people, but I have relapsed again. Finally made the cage ". (P10)

Participants felt bored because patients gradually had difficulty taking medicine, the following statement:

"At first, I wanted to take medicine for a long time, why didn't I want it, so I finally Injected it". (P9)

\section{Feel frustrated with the patient's condition}

Frustration is a feeling of disappointment because of failure in doing something, is an affective response that often arises when expectations are not in line with the reality that occurs. Participants felt disappointed because their children had a mental disorder which according to him was caused by the husband who left him when the children were small. Feeling disappointed felt influence on parenting to children. Overprotective behavior in children causes children to be less independent. Fatigue caring for children who have mental disorders cause anger with marked intonation when talking and tense faces. Anger a natural thing experienced by humans because of patience that is continually tested. Angry because the property was gone to find medicine, but his child did not recover. Disappointment,(Reknoningsih et al., 2015). The confinement carried out caused conflict in the community, the family felt ashamed because the act of containment was known by the community.

\section{Feeling annoyed because of patient disobedience}

Anger is a response when something is annoying. The family is upset because the patient did not listen to the advice of parents who cause the disease to get worse. Efforts that have been made by the family seem useless because the patient is not obedient. Willingness to perform self-care began to decline, bathing had to be told even forced. Taking medication must also be reminded that even medicine is given by stealth or rewarded so that the drug can be taken by the patient. Patient noncompliance with medication is a problem that many schizophrenic clients experience. Families as caregivers are required to be able to overcome this problem(Wardani et al., 2012), but the family cannot continue to watch over the patient. families must earn a living or care for other family members so that the patient's behavior often irritates the family. 


\section{The powerlessness of the family to do something}

The family feels scared and confused by the patient's behavior, does not dare to force the patient to follow his advice. The family feels trembled and helpless facing the patient because of past experiences that the patient has done. Disease that often recurs even though the drug is routinely taken causes family confusion, do not know what to do. Every effort has been made so that patients can recover until their possessions are used up. The patient's aggressive behavior and stigma in the community which states that mounting is one way to treat patients, is widely believed by families and communities. Lack of information about correct handling of ODGJ causes families and communities to put up with reasons to secure ODGJ and the environment(Laila et al., 2019). They realize that violating human rights violations and ODGJ experience social isolation because the location of the shelter is far from the settlement, the needs of selfcare are ignored(Daulima et al., 2018). Proper education to families and the community about ODGJ handling is needed so that the practice of retention does not happen again.

\section{Bored because there are no significant developments in patients.}

The family and the community consider that the illness suffered by the patient is due to the influence of witchcraft, so that treatment is done to the shaman with an expensive fee to perform the rituals according to the instructions of the shaman. New familyrealize that the patient has an illness after his possessions are gone, but the patient's condition has worsened. Treatment for ODGJ requires a long time because the condition has worsened. The condition of patients who do not heal, wealth has been used up causing boredom in the family and cause stress. Stress can arise as a result of problems or negative life events and conditions that are not in line with expectations(Stuart, 2016). The family also feels bored having to force patients to take medicine and keep giving medication clandestinely.

\section{CONCLUSION}

Research on the reasons for families to save people with mental disorders in Trenggalek District produces four themes. The theme is feeling frustrated with the patient's condition, feeling upset because of the patient's disobedience, the helplessness of the family doing something, bored because there is no meaningful development in the patient. Families incalculate people with mental disorders because they feel frustrated and helpless with the condition of patients who do not heal.

\section{REFERENCES}

1. Hjemdal, O., Friborg, O., Stiles, T. C., Martinussen, M., \& Rosenvinge, J. H. (2006). A new scale for adolescent resilience: Grasping the central protective resources behind 
healthy development. Measurement and evaluation in Counseling and Development, 39(2), 84-96.

2. Molodynski, A., O'Brien, A., \& Burns, J. (2017). Key international themes in coercion. BJPsych international, 14(3), 61-63.G, W, Stuart ,. (2016). Principles and Practices of Mental Health Nursing. In BA Keliat \& J. Pasaribu (Eds.), 2. Elsevier Ltd.

3. Minas, H., \& Diatri, H. (2008). Pasung: Physical restraint and confinement of the mentally ill in the community. International Journal of Mental Health Systems, 2(1), 8.

4. Purba, J. M. (2017). Caregivers'needs in caring for relative with schizophrenia in medan indonesia: A Phenomenological study. Belitung Nursing Journal, 3(6), 656-661.

5. Nugroho, T. W. A. (2017). Analisis E-Government Terhadap Pelayanan Publik Di Kementerian Hukum Dan Ham (Analysis Of E-Government To Public Services In The Ministry Of Law And Human Rights). Jurnal Ilmiah Kebijakan Hukum, 10(3), 279-296.

6. Laila, N. H., Mahkota, R., Shivalli, S., Bantas, K., \& Krianto, T. (2019). Factors associated with pasung (physical restraint and confinement) of schizophrenia patients in Bogor regency, West Java Province, Indonesia 2017. BMC psychiatry, 19(1), 162.

7. Helena, R. N., Daulima, C., \& Wardani, I. Y. (2018). The experience of people with mental disorders in social function adaptation after suffering from pasung. Enfermeria clinica, 28, 275-279.

8. Cahill, P. J., Sanderson, C. R., Lobb, E. A., \& Phillips, J. L. (2018). The VOICE Study: Valuing Opinions, Individual Communication and Experience: building the evidence base for undertaking Patient-Centred Family Meetings in palliative care-a mixed methods study. Pilot and feasibility studies, 4(1), 51.

9. Van Scoy, L. J., Green, M. J., \& Volpe, R. (2019). Evaluating an advance care planning curriculum: A lecture, a game, a patient, and an essay. Medical Science Educator, 29(2), 453-462. 